\title{
Chemical Composition, Antioxidant and In vitro Antibacterial Activities of Essential Oils of Mentha spicata Leaf from Tiaret Area (Algeria)
}

\author{
Sidi Mohammed Ammar Selles ${ }^{1,2,3}$, Mokhtaria Kouidri' ${ }^{2}$, Yuva Bellik ${ }^{4}$, \\ Amar Ait Amrane ${ }^{1,2}$, Belkacem Tahar Belhamiti ${ }^{1,2}$, Ahmed Redha Benia ${ }^{1,2}$ \\ Si Mohamed Hammoudi ${ }^{1}$ and Laid Boukraa ${ }^{1,2}$
}

\author{
${ }^{1}$ Laboratory of Research on Local Animal Products, Ibn-Khaldoun University of Tiaret, Tiaret 14000, Algeria \\ ${ }^{2}$ Institute of veterinary science, Ibn-Khaldoun University of Tiaret, Tiaret 14000, Algeria \\ ${ }^{3}$ Faculty of Life and Nature Sciences, Mascara University, Algeria \\ ${ }^{4}$ Faculty of Life and Nature Sciences, Mohamed El Bachir El Ibrahimi University, Bordj Bou Arreridj, 34000 \\ Algeria
}

(Received: 9 August, 2017; Accepted: 17 April, 2018; Published (web): 10 June, 2018)

\begin{abstract}
The antioxidant and antibacterial activities and the composition of essential oil of Mentha spicata from Tiaret area were evaluated. The essential oil was obtained by hydrodistillation. The antioxidant activity was determined by DPPH radical scavenging assay and reducing power. The antimicrobial activity was evaluated by the broth microdilution method against seven strains isolated from diarrhea of young calves. The essential oil was analyzed by GCMS/GC-FID. A total of 116 compounds amounting of $99.92 \%$ of the total component of the oil were identified. The major component of the oil was carvone (63.59\%).The antioxidant activity by DPPH assay showed $\mathrm{IC}_{50}$ value of 21.1 $\pm 7.17 \mu \mathrm{g} / \mathrm{ml}$, while the reducing power assay have resulted an $\mathrm{EC}_{50}$ value of $2.28 \pm 0.68 \mu \mathrm{g} / \mathrm{ml}$. The results showed that the essential oil exhibited an MIC against all tested bacteria at $2.37 \mathrm{mg} / \mathrm{ml}$ to $4.75 \mathrm{mg} / \mathrm{ml}$. The essential oil of $M$. spicata showed strong antioxidant and weak to moderate antibacterial activities.
\end{abstract}

Key words: Mentha spicata, essential oil, antimicrobial activity, antioxidant activity, enteropathogens bacteria.

\section{INTRODUCTION}

In the livestock industry, antimicrobial agents are used in chemoprophylaxis, chemotherapy and as growth promoters, but the misuse or abuse of these agents has the potential to result in a serious increase in resistance amongst bacteria. ${ }^{1}$ Additionally, antimicrobial resistance is an emerging and serious public health concern due to the compromised efficacy of antimicrobial agents used in the treatment of infectious diseases. ${ }^{2}$

Medicinal plants are the boon of nature to cure a number of ailments of human beings. In many parts of the world, medicinal plants are used against

Correspondence to: Selles Sidi Mohammed Ammar E-mail: nuider10@yahoo.fr; Tel: +213-554-200-199 Fax: + 21346427161 .

Dhaka Univ. J. Pharm.Sci. 17(1): 87-96, 2018 (June) bacterial, viral and fungal infections. ${ }^{3}$ In fact, medicinal plants are rich sources of bioactive secondary metabolites, including polyphenols and essential oils. The latters are especially obtained from aromatic plants by steam distillation or solvent extraction. Essential oil contains several chemical compounds exhibiting different biological activities. It can reduce foodborne pathogens and decrease the use of synthetic and semisynthetic antimicrobial compounds. ${ }^{4}$

The genus Mentha includes 25-30 species that grow under cultivation from tropical to temperate climate of many countries. ${ }^{5}$ Mentha spicata is one the most common and popular mint cultivated throughout the world. ${ }^{6}$ In Algeria, this species is locally known as 'Naanaa' and is cultivated all over 
the country for culinary purposes as well as for its medicinal properties. ${ }^{7}$ The leaves are popularly used as tea flavouring agent and the whole plant is used as carminative. The fresh and dried plants and their essential oils are widely used in the food, cosmetic, confectionary, chewing gum, toothpaste, and pharmaceutical industries. ${ }^{5}$ Likewise, $M$. spicata has been extensively applied to treat various diseases such as nausea, vomiting, and gastrointestinal disorders and also as breath freshener, antiseptic mouth rinse, and in toothpaste. ${ }^{6}$

The aim of the present study was to determine the chemical composition of the essential oil of Algerian spearmint, growing in the Dahmouni Locality (Tiaret), and to evaluate their antioxidant and antimicrobial effects against several pathogenic bacteria isolated from diarrhea of young calves.

\section{MATERIALS AND METHODS}

Extraction of essential oil. Aerial part of $M$. spicata was harvested in June, July and August 2014 in Ouled Bougadou (Dahmouni, Tiaret) located at west Algeria. The collected leaves were cut into small pieces and shade dried at room temperature and obscurity. The essential oil was extracted by hydrodistillation for $1 \mathrm{H} 30$ ' by mixing $25 \mathrm{~g}$ of $M$. spicata in $500 \mathrm{ml}$ of distilled water. The oil obtained was collected and dried over anhydrous sodium sulfate and stored in sealed glass vials in a refrigerator at $4^{\circ} \mathrm{C}$ prior to analysis. The percentage yield of $M$. spicata essential oil has been calculated using the following formula.

Yield of essential oil $=\frac{\text { Essential oil weight }(\mathrm{g})}{\text { Sample weight }(\mathrm{g})} \times 100$

Analysis of essential oil. The essential oil from leaves of $M$. spicata was analysed by gas chromatography (GC-FID) and gas chromatographymass spectrometry (GC/MS) realized by Pyrenessences Analysis. Briefly, the oil was analyzed using a Hewlett Packard 5973 instrument, with HP INNOWAX polar column $(60 \mathrm{~m} \times 0.25 \mathrm{~mm} \times 0.25$ $\mu \mathrm{m})$. One microliter of essential oil solution diluted in ethanol (10\%) was injected and analysed. Helium was the carrier gas with a flow rate of $30 \mathrm{psi} / \mathrm{FID}, 23$ psi/MS. Column temperature was initially kept at $60^{\circ} \mathrm{C}$ for $6 \mathrm{~min}$ and then gradually increased to $250^{\circ} \mathrm{C}$ at $2^{\circ} \mathrm{C} / \mathrm{min}$ rate and finally held for $10 \mathrm{~min}$ at $250^{\circ} \mathrm{C}$. The temperature of the injector was fixed to $250^{\circ} \mathrm{C}$ and one of the detectors (FID) to $270^{\circ} \mathrm{C}$. The compounds were identified by a combined search of retention time and mass spectra (NKS library, 75.000 spectra). The percentages were calculated from the peak areas given by the GC/ FID, without the use of correction factor.

\section{Antimicrobial study}

Microorganisms. The antimicrobial activity of the essential oil of $M$. spicata was evaluated against seven strains of Gram-negative bacteria (Escherichia coli F5, E. coli F17, E. coli CS31A, Kluyvera spp., Klebsiella spp., Salmonella spp. and Serratia spp.). The microbial strains used in this study were isolated from diarrhea of young calves.

Preparation of inoculum. Prior to the experiment, the strains were inoculated onto the surface of MacConkey agar media, the inoculum suspensions were obtained by taking five colonies from $24 \mathrm{~h}$ cultures. The colonies were suspended in 5 $\mathrm{ml}$ of sterile saline $(0.85 \% \mathrm{NaCl})$ and shaken for 15 seconds. The density was adjusted to the turbidity of a $0.5 \mathrm{McF}$ arland Standard (equivalent to $1-5 \times 10^{8}$ $\mathrm{cfu} / \mathrm{ml})$.

Minimum inhibitory concentration (MIC) measurement. The broth micro-dilution method employed for the determination of antimicrobial activities of the essential oils was performed according to the recommendations of the National Committee for Clinical Laboratory Standards. ${ }^{8}$ Minimum inhibitory concentration determination was performed by a serial dilution method in 96 well microtiter plates. The starting concentration of the essential oil solution was $9.5 \mathrm{mg} / \mathrm{ml}$. Further, stock solutions of the essential oils were prepared in $10 \%$ aqueous Tween 20 and then double serial dilutions of the oils were made. The inoculum was added to all wells and the plates were incubated at $37^{\circ} \mathrm{C}$ for $24 \mathrm{~h}$. The bacterial growth was visualized by adding $20 \mu \mathrm{l}$ 
of $0.5 \%$ 2,3,5-triphenyltetrazolium chloride (TTC) aqueous solution. ${ }^{9}$ Minimum inhibitory concentration (MIC) was defined as the lowest concentration of the oils that inhibited visible growth (red-colored pellet at the bottom of the wells after the addition of TTC), while the minimum bactericidal concentration (MBC) was defined as the lowest concentration that killed 99.9\% of bacterial cells. To determine MBC, broth was taken from each well without visible growth and inoculated on Mueller Hinton agar for $24 \mathrm{~h}$ at $37^{\circ} \mathrm{C}$. The experiments were done in triplicate.

Antibiotic susceptibility test. Susceptibility to a panel of antimicrobial agents was determined by the standardized disc diffusion assay on Mueller-Hinton agar with commercial antimicrobial susceptibility discs according to the recommendations of committee on standardization of susceptibility testing in veterinary medicine. ${ }^{10,11}$ The antibiotics tested and their corresponding disc concentrations were as follows: amoxicillin + clavulanic acid $(20 / 10 \mu \mathrm{g})$, ampicillin $(10 \mu \mathrm{g})$, gentamicin $(10 \mu \mathrm{g})$, tetracycline $(10 \mu \mathrm{g})$, colistin $(10 \mu \mathrm{g})$, trimethoprime/ sulfamethoxazole $(1.25 / 23.75 \mu \mathrm{g})$, ofloxacine $(5 \mu \mathrm{g})$ and cifotaxime $(30 \mu \mathrm{g})$. The plates were then incubated at $37{ }^{\circ} \mathrm{C}$ for $24 \mathrm{~h}$ to $48 \mathrm{~h}$. The diameter of zone of inhibition was recorded and the data was interpreted using the recommendation of committee on standardization of susceptibility testing in veterinary medicine. $^{10,11}$

\section{Antioxidant activity}

Reducing power. The $\mathrm{Fe}^{3+}$ reducing power of essential oil was determined by the method of Yen and Duh ${ }^{12}$ with some modifications. Essential oil was mixed with $2.5 \mathrm{ml}$ of phosphate buffer $(0.2 \mathrm{M}, \mathrm{pH}$ 6.6) and $2.5 \mathrm{ml}$ of $1 \%$ potassium ferricyanide. The mixture was incubated for $20 \mathrm{~min}$ at $50{ }^{\circ} \mathrm{C}$. After incubation, $2.5 \mathrm{ml}$ of trichloroacetic acid (10\%) was added to the mixture followed by centrifugation at $3000 \mathrm{rpm}$ for $10 \mathrm{~min}$. The upper layer $(1 \mathrm{ml})$ was mixed with $1 \mathrm{ml}$ of distilled water and $0.5 \mathrm{ml}$ of ferric chloride $(0.1 \%)$. The absorbance of the obtained solution was measured at $700 \mathrm{~nm}$. A higher absorbance indicates a higher reducing power. All tests were carried out in triplicate. Quercetin and ascorbic acid were used as positive controls.

DPPH radical-scavenging assay. The capacity to scavenge the "stable" free radical 2,2-diphenyl-1picrylhydrazyl (DPPH) was assessed according to the method described previously. ${ }^{13}$ Two $\mathrm{ml}$ of various concentrations of essential oil of M. spicata was added to $0.4 \mathrm{ml}$ solution of DPPH radical in ethanol (final concentration of DPPH was $0.5 \mathrm{mM}$ ). The mixture was shaken and kept in the dark for $30 \mathrm{~min}$ and the absorbance of the resulting solution was measured at $517 \mathrm{~nm}$. Inhibition of free radical DPPH in percent (DPPH I\%) was calculated as follows:

$$
\text { DPPH I } \%=100 \mathrm{X}\left(\mathrm{A}_{\text {blank }}-\mathrm{A}_{\text {sample }}\right) / \mathrm{A}_{\text {blank }} \text {, }
$$

where $A_{\text {blank }}$ represents the absorbance of the control reaction (containing all reagents except the tested compound), and $\mathrm{A}_{\text {sample }}$ represents the absorbance of the tested compound. Gallic acid, quercetin and ascorbic acid were used as positive controls.

Statistical analysis. The assays were performed in triplicate and the results were expressed as the mean values with standard deviations (SD). The significant differences were obtained by a one-way analysis of variance (ANOVA) followed by Tukey's honestly significant difference (HSD) post hoc test ( $p$ $<0.05)$. These statistical analyses were calculated using R software (version 3.3.0/ 2016-05-03).

\section{RESULTS AND DISCUSSION}

The yield of the oil obtained from M. spicata was $1.97 \pm 0.09 \%$. Our results are in agreement with those of Soković et.al. ${ }^{14,15}$ They found that the yield of essential oil was $1.5 \%$. The yield of essential oils from M. spicata leaves harvested in three other regions of Algeria (Bejaia Saida and Setif) was 1.1\%, $1.3 \%$ and $0.89 \%$, respectively. ${ }^{7,16,17}$

However, the extraction yield of Tunisian spearmint was $1.1 \%,{ }^{5}$ Pakistan spearmint $1.2 \%,{ }^{18}$ Indian spearmint ranged from $0.4-0.8 \%,{ }^{19}$ and Bangladeshi spearmint was $0.33 \% .{ }^{20}$ On the other hand, Roldán et $a l^{21}$ and Martins et $a .^{22}$ have shown very lower rate with 0.08 and $0.1 \%$, respectively. 
However, M. spicata is known to have a minimum of $10 \mathrm{ml} / \mathrm{kg}$ of essential oil. ${ }^{23}$

The difference in yield can be attributed to the harvest season of the plant when a high essential oil yield was seen in summer (when the plants were in full bloom) than in winter (when the plants reached the end of their growing cycle), ${ }^{7,24,25}$

The composition of essential oils of $M$. spicata is presented in table 1. One hundred and sixteen compounds were identified accounting for $99.92 \%$ of the total amount. The main constituents were carvone (63.59\%), followed by limonene (5.85\%), dihydrocarvyl acetate $(4.17 \%), 1,8$-cineole $+\beta$ phellandrene $(3.75 \%)$, trans-thujanol $(2.74 \%)$, cisdihydrocarvone (1.68\%), $\beta$-caryophyllene $(1.37 \%)$, terpinen-4-ol $(1.23 \%)$, borneol $(1.11 \%)$ and ciscarvyl acetate $(1.07 \%)$.

There is large variation in the chemical composition of M. spicata between the wild as well as cultivated samples around the world. Indeed, a series of chemotypes have been described in previous studies. Recently, Brahmi et al. ${ }^{7}$ studied the chemical composition of $M$. spicata essential oil originating from Bejaia locality (Algeria) and reported that carvone (48.5\%), limonene (20.8\%), 1,8-cineole $(5.4 \%), \quad \beta$-caryophyllene $(3.4 \%)$, germacrene D (3.4\%) and $\beta$-pinene $(1.1 \%)$ as the major components. Likewise, Allali et al. ${ }^{16}$ reported carvone (48.42\%), eucalyptol (17.6\%) and neoisodehydrocarveol acetate $(11.7 \%)$ as the main components of the essential oil collected from Saida (west northern region of Algeria). M. spicata collected from Amoucha, Setif locality (north east Algeria) showed carvone $(59.40 \%)$ followed by limonene $(6.12 \%), \quad 1,8$-cineole, germacrene-D (04.66\%), $\beta$-caryophyllene (2.969\%), $\beta$-bourbonene $(2.796 \%), \alpha$-terpineol (1.986\%) and terpinen-4-ol $(1.120 \%)$ in its oils. ${ }^{17}$ M. spicata growing in other countries also contains carvone as one of the major components of its essential oil, e.g., Portugual $(41.1 \%)^{22}$, Morocco $(29.0 \%)^{26}$, Bangladesh $(73.29 \%)^{20}$ and Serbia $(49.52 \%) .{ }^{15}$

Nevertheless, Dhifi et $a l .{ }^{27}$ demonstrated an entirely different oil composition of $M$. spicata harvested in Tunisia, where menthone $(32.7 \%)$ and pulegone (26.6\%) was found as the major constituents. Even, Telic et al. ${ }^{28}$ in Turkey, reported linalool (82.8\%) chemotype of M. spicata. The variations in chemical composition of the essential oils with respect to season might have been due to the influence of phenological status, and environmental conditions can influence the regulation of the biosynthesis of essential oil. Previous investigations have demonstrated that harvesting season can alter the chemical composition of the essential oils of $M$. spicata. ${ }^{24}$ Other explanation for the differences in oil content and composition may be attributed to factors related to ecotype, phenophases, temperature, relative humidity, photoperiod, irradiance, genotype, and agronomic conditions (harvesting time, plant age, crop density). ${ }^{5}$ In addition, the duration of sunshine, the movement of air and precipitation can play roles in the difference in composition of essential oils. ${ }^{17}$

Two antioxidant assays have been used to evaluate the possible antioxidant properties of the spearmint oil, including ferric reducing power and DPPH radical scavenging activity. The results obtained (Table 2) confirm the previous reports about the importance of essential oils as natural antioxidants. Reducing power measures the ability of an antioxidant to donate an electron. ${ }^{29}$ These antioxidants trap the free radicals, act on certain peroxide precursors, and prevent the peroxidation chain reaction. ${ }^{30}$ The assayed sample was able to reduce the ferric ions $\left(\mathrm{Fe}^{3+}\right)$ to corresponding ferrous ions $\left(\mathrm{Fe}^{2+}\right)$. The $\mathrm{EC}_{50}$ value for spearmint essential oil was $2.28 \pm 0.68 \mu \mathrm{g} / \mathrm{ml}$ in comparison to $21.22 \pm 1.66$ $\mu \mathrm{g} / \mathrm{ml}$ and $13.98 \pm 1.99 \mu \mathrm{g} / \mathrm{ml}$ for the standard compound quercetin and ascorbic acid, respectively. Brahmi et al. ${ }^{7}$ and Snouci et al. ${ }^{5}$ reported that the $\mathrm{EC}_{50}$ value of the M. spicata essential oil harvested from north Algeria and northeast of Tunisia were about $452.3 \pm 0.4 \mu \mathrm{g} / \mathrm{ml}$ and $2.49 \pm 0.07 \mu \mathrm{g} / \mathrm{ml}$, respectively. 
Table 1. Chemical composition of essential oil.

\begin{tabular}{|c|c|c|c|}
\hline Pick & $\mathrm{RT}(\min )$ & Components & $\%$ \\
\hline 1 & 7.2 & Ethanol & 0.1 \\
\hline 2 & 10.5 & $\alpha$-Pinene & 0.48 \\
\hline 3 & 10.6 & $\alpha$-Thujene & 0.08 \\
\hline 4 & 11.4 & Trans-2,5-diethyltetrahydrofuran & 0.01 \\
\hline 5 & 11.7 & Ethyl 2-methylbutyrate & 0.01 \\
\hline 6 & 12.6 & Camphene & 0.2 \\
\hline 7 & 14.7 & $\beta$-Pinene & 0.74 \\
\hline 8 & 15.4 & Sabinene & 0.56 \\
\hline 9 & 17.6 & $\beta$-Myrcene & 0.61 \\
\hline 10 & 18.0 & $\alpha$-Phellandrene & 0.01 \\
\hline 11 & 18.2 & $\psi$-Limonene & 0.02 \\
\hline 12 & 18.9 & $\alpha$-Terpinene & 0.17 \\
\hline 13 & 20.1 & Limonene & 5.85 \\
\hline 14 & 20.9 & 1,8 -cinaeole $+\beta$-phellandrene & 3.75 \\
\hline 15 & 21.2 & 1,3,8-p-menthatriene & 0.03 \\
\hline 16 & 21.4 & 2-hexenal & 0.02 \\
\hline 17 & 22.1 & Cis- $\beta$-ocimene & 0.18 \\
\hline 18 & 23.1 & $\gamma$-terpinene & 0.34 \\
\hline 19 & 23.3 & Trans- $\beta$-ocimene & 0.05 \\
\hline 20 & 24.8 & $p$-cymene & 0.23 \\
\hline 21 & 25.1 & 2-Metthyl butyl 2- methyl butyrate & 0.01 \\
\hline 22 & 25.3 & 3-Heptanol & 0.02 \\
\hline 23 & 25.6 & Terpinolene & 0.1 \\
\hline 24 & 28.9 & 1-Ethylhexyle acetate & 0.12 \\
\hline 25 & 30.5 & Aliphatic ester & 0.01 \\
\hline 26 & 32.6 & 3-Octanol & 0.4 \\
\hline 27 & 33.3 & Nonanal & 0.03 \\
\hline 28 & 35.9 & Aliphatic ester & 0.02 \\
\hline 29 & 36.2 & $\alpha, p$-Dimethylstyrene & 0.02 \\
\hline 30 & 36.4 & 1-Octen-3-ol & 0.06 \\
\hline 31 & 37 & Cis-1,2-limonene epoxide & 0.01 \\
\hline 32 & 37.8 & Trans-thujanol & 2.74 \\
\hline 33 & 38 & Trans-limonene 1,2- epoxide & 0.06 \\
\hline 34 & 38.4 & Cis-2- hexenyl methyl butyrate & 0.01 \\
\hline 35 & 38.5 & Menthone & 0.01 \\
\hline 36 & 39.3 & 3-Nonanol & 0.01 \\
\hline 37 & 39.4 & Cis-3-hexenyl methyl butyrate & 0.08 \\
\hline 38 & 40.2 & $\alpha$-Copaene & 0.02 \\
\hline 39 & 40.3 & Isomenthone & 0.02 \\
\hline 40 & 41.6 & $\alpha$-Bourbonene & 0.03 \\
\hline 41 & 42 & $\beta$-Bourbonen & 0.41 \\
\hline 42 & 42.2 & Dihdroedulan isomer & 0.03 \\
\hline 43 & 42.9 & Linalool & 0.03 \\
\hline
\end{tabular}




\begin{tabular}{|c|c|c|c|}
\hline 44 & 43.1 & Aliphatic alcohol & 0.03 \\
\hline 45 & 43.4 & Cis-thujanol & 0.21 \\
\hline 46 & 43.6 & 1-Octanol & 0.02 \\
\hline 47 & 44.1 & Isomeric limonene epoxide & 0.01 \\
\hline 48 & 44.4 & Trans-p-menth-2-en-1-ol & 0.1 \\
\hline 49 & 45.7 & $\varepsilon$-Cadinene & 0.08 \\
\hline 50 & 45.9 & Bornyl acetate & 0.09 \\
\hline 51 & 46.5 & $\beta$-Elemene & 0.09 \\
\hline 52 & 46.9 & $\beta$-Cubebene & 0.06 \\
\hline 53 & 47.1 & Terpinen-4-ol & 1.23 \\
\hline 54 & 47.3 & $\beta$-Caryophyllene & 1.31 \\
\hline 55 & 48 & Cis-dihydrocarvone & 1.68 \\
\hline 56 & 48.5 & Cis-p-2,8-menthadien-1-ol & 0.06 \\
\hline 57 & 49.1 & Trans-dihydrocarvone & 0.15 \\
\hline 58 & 49.8 & Cadina-3,5- & 0.1 \\
\hline 59 & 50 & Isomeric cadinadiene & 0.05 \\
\hline 60 & 50.2 & Allo-aromadendrene & 0.03 \\
\hline 61 & 50.4 & Trans-pinocarveol & 0.02 \\
\hline 62 & 50.9 & E- $\beta$-Farnesene & 0.04 \\
\hline 63 & 51.2 & Trans-p-2,8-menthadien-1-ol & 0.05 \\
\hline 64 & 51.3 & $\delta$-Terpineol & 0.23 \\
\hline 65 & 51.5 & Dihydrocarvyl acetate & 4.17 \\
\hline 66 & 51.9 & $\alpha$-Humulene & 0.14 \\
\hline 67 & 52 & Cis-4,5-Muuroladiene & 0.47 \\
\hline 68 & 52.3 & Sesquiterpene & 0.06 \\
\hline 69 & 52.9 & $\alpha$-Terpineol & 0.32 \\
\hline 70 & 53.2 & Borneol & 1.11 \\
\hline 71 & 54.4 & Germacrene D & 0.96 \\
\hline 72 & 54.7 & Dihydrocarveol isomer & 0.16 \\
\hline 73 & 55.4 & Trans-carvyl acetate & 0.03 \\
\hline 74 & 56.1 & Carvone & 63.59 \\
\hline 75 & 56.3 & Bicyclogermacrene & 0.4 \\
\hline 76 & 56.9 & $\delta$-Cadinene & 0.04 \\
\hline 77 & 57.2 & $\gamma$-Cadinene & 0.07 \\
\hline 78 & 57.5 & Cis-carvyl acetate & 1.07 \\
\hline 79 & 58.1 & Methyl salicylate & 0.03 \\
\hline 80 & 58.8 & Nerol & 0.02 \\
\hline 81 & 58.9 & Perillaldehyde & 0.03 \\
\hline 82 & 59.2 & $\alpha$-amorphene & 0.09 \\
\hline 83 & 59.3 & Terpenic alcohol & 0.04 \\
\hline 84 & 59.9 & Terpenic ester & 0.02 \\
\hline 85 & 60.9 & Trans-carveol & 0.21 \\
\hline 86 & 61.5 & Calamenene & 0.35 \\
\hline 87 & 61.6 & p-cymen-8-ol & 0.04 \\
\hline 88 & 62 & Carvone oxide & 0.03 \\
\hline 89 & 62.3 & E-geranyl acetone & 0.03 \\
\hline 90 & 62.7 & Cis-carveol & 0.58 \\
\hline
\end{tabular}




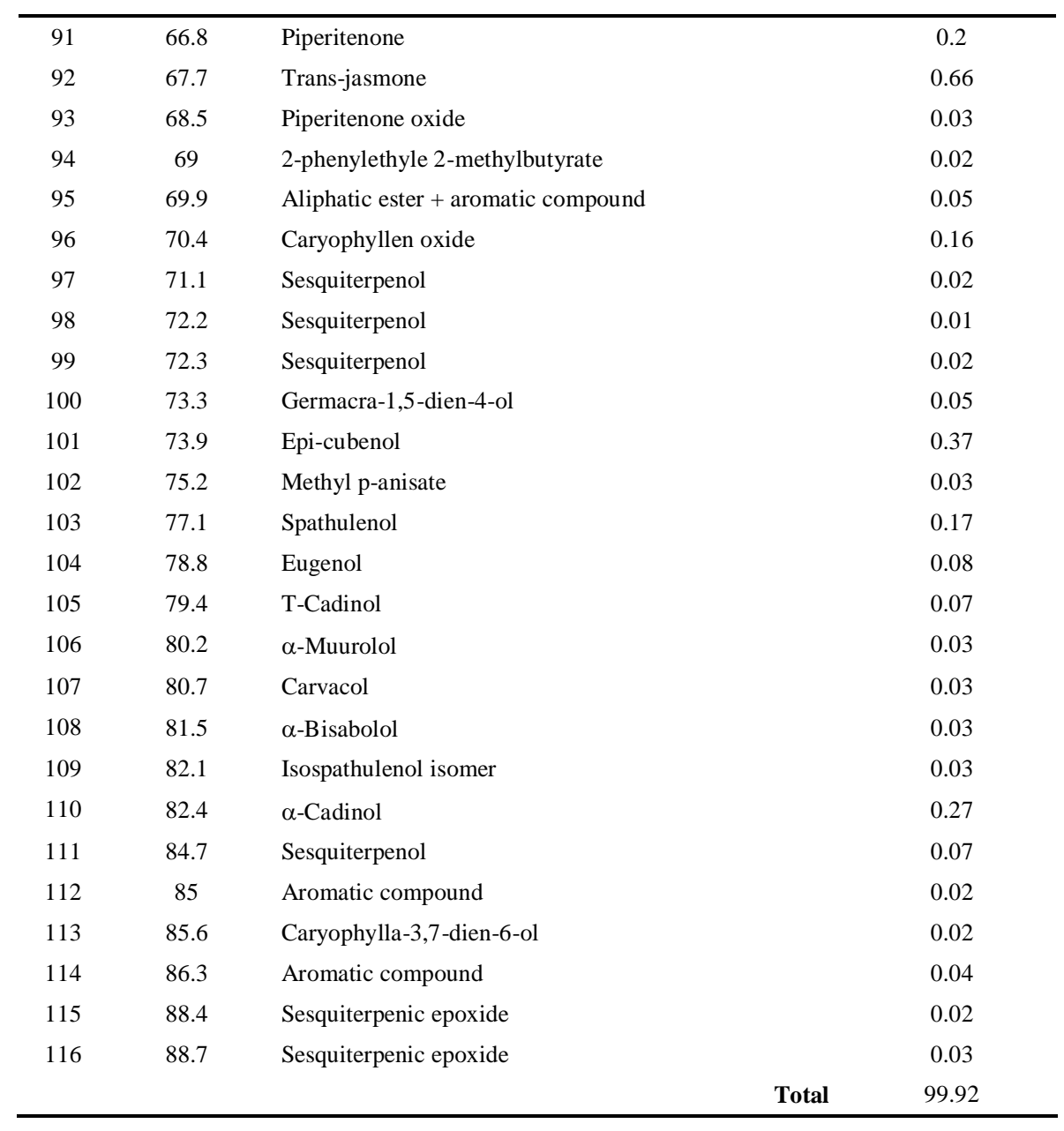

DPPH assay has been widely used for the evaluation of free radical scavenging activity of plant extracts, food material or single compounds. ${ }^{31}$ It has been established that the bleaching of the DPPH solution increased regularly with increasing amount of polyphenols. ${ }^{29}$ Table 2 summarizes the results of the antiradical activity expressed as percentage inhibition of DPPH. The $\mathrm{IC}_{50}$ value for M. spicata essential oil was $21.19 \pm 7.17 \mu \mathrm{g} / \mathrm{mL}$ in comparison to the standard compound.

The $\mathrm{IC}_{50}$ obtained in our study is superior to those cited by Snoussi et al. ${ }^{5}$ with a value of $3.08 \pm$ $0.07 \mu \mathrm{g} / \mathrm{ml}$, Hussain et al. ${ }^{18}$ showed the $\mathrm{IC}_{50}$ value of $13.3 \pm 0.6 \mu \mathrm{g} / \mathrm{ml}$, and Dhifi et al. ${ }^{27}(10 \pm 0.24 \mu \mathrm{g} /$ $\mathrm{ml}$ ) but much lower than those registered by Brahmi et al. ${ }^{7}$, Moldovan et al. ${ }^{32}$, Allali et al. ${ }^{16}$, Soni and Sosa $^{33}$, Ebrahimzadeh et al. ${ }^{34}$ and Nickavar et. al. ${ }^{35}$ with $9544.6 \pm 0.196 \mu \mathrm{g} / \mathrm{ml}, 151.05 \pm 1.95 \mu \mathrm{g} / \mathrm{ml}$,
$10620 \mu \mathrm{g} / \mathrm{ml}, 170 \mu \mathrm{g} / \mathrm{ml}, 105.8 \pm 3.98 \mu \mathrm{g} / \mathrm{ml}$ and $87.89 \mu \mathrm{g} / \mathrm{ml}$, respectively. Snoussi et al. ${ }^{5}$ and Soni and Sosa $^{33}$ showed that the essential oil $\mathrm{IC}_{50}$ was lower than standards used, which is in agreement with our study. This interesting biological activity can be explained by the presence of the monoterpenes limonene, terpinolene, $\gamma$-terpinene, 1,8-cineole and carvone. ${ }^{5}$

Regarding the antibiotic susceptibility, all tested strains were resistant to ampicillin, amoxicillin + clavulanic acid, tetracycline, trimethoprime/ sulfamethoxazole and ofloxacine (table 3). The antimicrobial activity of essential oil of $M$. spicataa gainst Gram-negative bacteria associated with neonatal calves diarrhoea is shown in table 4 .

In our study, the essential oil of $M$. spicata showed moderate activity against bacterial strains 
selected. Results obtained from minimum inhibitory concentration method, indicated that $E$. coli $\mathrm{F} 5, E$. coli CS31A, Salmonella spp., Kluyvera spp. and Klebsiella spp. were the most sensitive bacteria among microorganisms tested, with lowest MIC values $(2.37 \mathrm{mg} / \mathrm{ml})$. The lowest activity was observed for $E$. coli F17 with highest MIC value $(>9.5 \mathrm{mg} / \mathrm{mL})$. The value of MBC $9.5 \mathrm{mg} / \mathrm{ml}$ were sufficient to kill E. coli CS31A and Klebsiella spp., whereas higher values of $\mathrm{MBC}(>9.5 \mathrm{mg} / \mathrm{ml}$ ) are needed to kill others bacteria tested in this study.

Table 2. Antioxidant activity of essential oil of M. spicata in reducing power and DPPH assays.

\begin{tabular}{lcc}
\hline & $\begin{array}{c}\text { Reducing power } \\
\left(\mathrm{EC}_{50}\right) \mu \mathrm{g} / \mathrm{ml}\end{array}$ & $\begin{array}{c}\mathrm{DPPH} \\
\left(\mathrm{IC}_{50}\right) \mu \mathrm{g} / \mathrm{ml}\end{array}$ \\
\hline Quercetin & $21.22 \pm 1.66^{\mathrm{c}}$ & $12.02 \pm 1.3^{\mathrm{a}, \mathrm{b}}$ \\
Gallic acid & - & $5.39 \pm 0.41^{\mathrm{b}}$ \\
Ascorbic acid & $13.98 \pm 1.99^{\mathrm{b}}$ & $6.19 \pm 0.97^{\mathrm{b}}$ \\
Essential oil of M. spicata & $2.28 \pm 0.68^{\mathrm{a}}$ & $21.19 \pm 7.17^{\mathrm{a}}$ \\
\hline
\end{tabular}

Each value in the table is represented as mean $\pm S D(n=3)$. Means not sharing the same letter are significantly different (LSD) at $P<0.05$ probability level in each column

Table 3. Antimicrobial susceptibility of selected microbial strains.

\begin{tabular}{lccccccc}
\hline Antibiotic & A & B & C & D & E & F & G \\
\hline Ampicillin $(10 \mu \mathrm{g})$ & & & & & & & \\
Amoxicillin+ clavulanicacid $(20 / 10 \mu \mathrm{g})$ & $\mathrm{R}$ & $\mathrm{R}$ & $\mathrm{R}$ & $\mathrm{R}$ & $\mathrm{R}$ & $\mathrm{R}$ & $\mathrm{R}$ \\
Gentamicin $(10 \mu \mathrm{g})$ & $\mathrm{R}$ & $\mathrm{R}$ & $\mathrm{R}$ & $\mathrm{R}$ & $\mathrm{R}$ & $\mathrm{R}$ & $\mathrm{R}$ \\
Tetracycline $(10 \mu \mathrm{g})$ & $\mathrm{R}$ & $\mathrm{R}$ & $\mathrm{R}$ & $\mathrm{R}$ & $\mathrm{S}$ & $\mathrm{I}$ & $\mathrm{S}$ \\
Colistin $(10 \mu \mathrm{g})$, & $\mathrm{R}$ & $\mathrm{R}$ & $\mathrm{R}$ & $\mathrm{R}$ & $\mathrm{R}$ & $\mathrm{R}$ & $\mathrm{R}$ \\
Trimethoprime/sulfamethoxazole $(1.25 / 23.75 \mu \mathrm{g})$ & $\mathrm{R}$ & $\mathrm{R}$ & $\mathrm{R}$ & $\mathrm{R}$ & $\mathrm{R}$ & $\mathrm{R}$ & $\mathrm{R}$ \\
Ofloxacine $(5 \mu \mathrm{g})$ & $\mathrm{R}$ & $\mathrm{R}$ & $\mathrm{R}$ & $\mathrm{R}$ & $\mathrm{R}$ & $\mathrm{R}$ & $\mathrm{R}$ \\
Cifotaxime $(30 \mu \mathrm{g})$ & $\mathrm{S}$ & $\mathrm{S}$ & $\mathrm{R}$ & $\mathrm{S}$ & $\mathrm{S}$ & $\mathrm{I}$ & $\mathrm{R}$ \\
\hline
\end{tabular}

A: E. coli F5, B: E. coli F17, C: E. coli CS31A, D: Klebsilla spp., E: Kluyvera spp.,

F: Salmonella spp., G: Serratia spp.

Table 4. Antimicrobial activity of essential oils of M. spicata.

\begin{tabular}{lcc}
\hline Bacteria & \multicolumn{2}{c}{$\begin{array}{c}\text { Essential oil of } \text { M. spicata } \\
(\mathrm{mg} / \mathrm{ml})\end{array}$} \\
\cline { 2 - 3 } & MIC & MBC \\
\hline Serratia spp. & 4.75 & $>9.5$ \\
Salmonella spp. & 2.37 & $>9.5$ \\
Kluyvera spp. & 2.37 & $>9.5$ \\
Klebsiella spp. & 2.37 & 9.5 \\
E. coli $\mathrm{F} 5$ & 2.37 & $>9.5$ \\
E. coli $\mathrm{F} 17$ & $>9.5$ & $>9.5$ \\
E. coli $\mathrm{CS} 31 \mathrm{~A}$ & 2.37 & 9.5 \\
\hline
\end{tabular}

Many previous studies reported a small MIC ranging from $0.21 \pm 0.01 \mathrm{mg} / \mathrm{ml}, 0.345 \pm 0.01 \mathrm{mg} / \mathrm{ml}$ to $0.349 \pm 0.008 \mathrm{mg} / \mathrm{ml}$ against $E$. coli. ${ }^{18,24}$ Likewise, Martins $e t ~ a l .{ }^{22}$ showed the MIC values ringing from
$250 \mu \mathrm{g} / \mathrm{ml}$ to $500 \mu \mathrm{g} / \mathrm{ml}$ against E. coli, Salmonella enteritidis and Klebsiella pneumonia. The lowest value of MIC $<3.5 \mu \mathrm{g} / \mathrm{ml}$ was reported by Sarer et al. $^{36}$ 
M. spicata essential oil was detected as active against only Klebsiella spp. and E. coli CS31A with MBC of $9.5 \mathrm{mg} / \mathrm{ml}$. Similar results were reported by Roldan et al. ${ }^{21}$ against E. coli ATCC 25922, E. coli O157:H7, Salmonella enteritidis ATCC13076 and Salmonella typhimurium ATCC14028. However, Sokovic et al. ${ }^{14}$ signalled lowest result of MBC (3 $\mu \mathrm{g} / \mathrm{ml})$. The antibacterial activity of $M$. spicata essential oil could be attributed to the presence of carvone and limonene. It has been reported that carvone is one of the most efficient antimicrobial agents of various plants. The mechanism of antibacterial activity of carvone is not completely understood in great detail. It has been demonstrated that the mechanism of action of carvone on the growth of microorganisms includes the destabilization of the phospholipid bilayer structure, interaction with membrane enzymes and proteins, ${ }^{6}$ it act as a proton exchanger reducing the $\mathrm{pH}$ gradient across the membrane $e^{6,37}$ and probably it could act by disrupting the metabolic energy state of the cells. In contrast, another study found that carvone was ineffective against the outer membrane of $E$. coli and $S$. typhimurium and did not affect their intracellular ATP pool. ${ }^{37}$

The present study revealed that the main component of the essential oil of $M$. spicata cultivated in the Tiaret region was the carvone, which is well corroborated with the results obtained in other Algerian regions. The essential oil of $M$. spicata showed a strong antioxidant activity and a weak to moderate antibacterial activity. These bioactivities are mainly due to the high content of carvone, in this species.

\section{Authors contributions}

Selles SMA supervised, controlled the laboratory work and wrote the first draft. Ait Amrane Ammar and Kouidri M designed the manuscript. Belhamiti TB and Benia AR helped to analyse experimental results. Bellik Y helped in data interpretation and discussion. Hammoudi SM and Boukraa lrevised the manuscript. All authors read and approved the final manuscript.

\section{REFERENCES}

1. Roopnarine, R., Ammons, D. and Adesiyun, A.A. 2009. Frequency of antimicrobial resistance of $E$. coli isolates from dairy farms in Trinidad by source and presence of virulence markers. Vet. Arhiv. 79, 229-243.

2. Ashraf, M.A., Younis, E.E.A., Osman, S.A., Ishida, Y., Elkhodery, S.A. and Shimamoto T. 2009. Genetic analysis of antimicrobial resistance in Escherichia coli isolated from diarrheic neonatal calves. Vet. Microbiol. 136, 397-402.

3. Padmini, E., Valarmathi, A. and Rani, $\square$ M.U. 2010. Comparative analysis of chemical composition and antibacterial activities of Mentha spicata and Camellia sinensis E. Asian J. Exp. Biol. Sci. 1, 772- 781.

4. Tsai, M.L., Wu, C.T., Lin, T.F., Wei-Chao Lin, W.C., Huang, Y.C. and Chao-Hsun Yang, C.H. 2013. Chemical composition and biological properties of essential oils of two mint species. Trop. J. Pharm. Res. 12, 577 -582.

5. Snoussi, M., Noumi, E., Trabelsi, N., Flamini, G., Papetti, A. and De Feo, V. 2015. Mentha spicata essential oil: chemical composition, antioxidant and antibacterial activities against planktonic and biofilm cultures of Vibrio spp. strains. Molecules 20, 14402-14424.

6. Shahbazi, Y. 2015. Chemical composition and in vitro antibacterial activity of Mentha spicata essential oil against common food-borne pathogenic bacteria. J. Pathog. 2015, 916305. doi: 10.1155/2015/916305

7. Brahmi, F., Adjaoud, A., Marongiu, B., Falconieri, D., Yalaoui-Guellal D., Madani, K. and Chibane, M. 2016. Chemical and biological profiles of essential oils from Mentha spicata L. leaf from Bejaia in Algeria. J. Essent. Oil. Res. 28, 211-220.

8. National Committee for Clinical Laboratory Standards (NCCLS). 1999. Performance Standards for Antimicrobial Susceptibility Test, 9th International Supplement. M100-S9, Clinical and Laboratory Standards Institute, Wayne, PA.

9. Radulovic, N., Dekic, M., Radic, Z. S. and Palic, R. 2011. Chemical composition and antimicrobial activity of the essential oils of Geranium columbinum L. and G. lucidum L. (Geraniaceae). Turk. J. Chem. 35, 499-512.

10. MoARD. 2008. Standardization of antimicrobial susceptibility testing in the veterinary medicine at the national level, according to WHO recommendations. Ministry of Agriculture and Rural Development, Ministry of Health, Population and Hospital Reform (Democratic and Popular Republic of Algeria), p. 83.

11. MoARD. 2011. Standardization of antimicrobial susceptibility testing in the veterinary medicine at the national level, according to WHO recommendations. Ministry of Agriculture and Rural Development, Ministry of Health, Population and Hospital Reform (Democratic and Popular Republic of Algeria), pp. 181-182.

12. Yen, G. C. and Duh, P. D. 1993. Antioxidative properties of methanolic extracts from peanut hulls. J. Am. Oil Chem. Soc. 70, 383-386. 
13. Tien, Y.Y., Ng, C.C., Chang, C.C., Tseng, W.S., Kotwal, S. and Shyu, Y.T. 2005. Studies on the lactic- fermentation of sugar apple (Annona squamosa L.) puree. J. Food. Drug. Anal. 13, 377-381.

14. Soković, M., Glamočlija, J., Marin, P. D., Brkić, D. and Van Griensven, L. J. 2010. Antibacterial effects of the essential oils of commonly consumed medicinal herbs using an in vitro model. Molecules 15, 7532-7546.

15. Soković, M., Marin, P.D., Brkić, D. and Van Griensven, L.J.2008. Chemical composition and antibacterial activity of essential oils of ten aromatic plants against human pathogenic bacteria. Food 1, 220-226.

16. Allali, H., Chikhi, I., Dib, M. E., Muselli, A., Fekih, N., N.Meliani, M. Kamal, A., Tabti B. and Costa, J. 2013. Antioxidant activity and chemical analysis of Mentha spicata cultivated from west northern region of Algeria by headspace solid phase micro-extraction and hydro-distillation. Nat. Prod. I. J. 9, 258-263.

17. Boukhebti, H., Chaker, A. N., Belhadj, H., Sahli, F., Ramdhani, M., Laouer H. and Harzallah, D. 2011. Chemical composition and antibacterial activity of Mentha pulegium L. and Mentha spicata L. essential oils. Pharm. Lett. 3, 267-275.

18. Hussain, A. I., Anwar, F. and Shahid, M. 2010. Chemical composition, and antioxidant and antimicrobial activities of essential oil of spearmint (Mentha spicata L.) from Pakistan. J. Essent. Oil. Res. 22, 78-84.

19. Padalia, R. C., Verma, R. S., Chauhan, A., Sundaresan, V. and Chanotiya, C. S. 2013. Essential oil composition of sixteen elite cultivars of Mentha from western Himalayan region, India. Maejo. Int. J. Sci. Technol. 7, 83-93.

20. Chowdhury, J. U., Nandi, N. C., Uddin, M. and Rahman, M. 2007. Chemical constituents of essential oils from two types of spearmint (Mentha spicata L. and M. cardiaca L.) introduced in Bangladesh. Bangl. J. Sci. Ind. Res. 42, 79-82.

21. Roldán, L. P., Gonzalo, J., Díaz, G. J. and Duringer, J. M. 2010. Composition and antibacterial activity of essential oils obtained from plants of the Lamiaceae family against pathogenic and beneficial bacteria. Rev. Colomb. Cienc. Реси. 23, 451-461.

22. Martins, M.R., Tinoco, M.T., Almeida, A.S. and CruzMorais, J. 2012. Chemical composition, antioxidant and antimicrobial properties of three essential oils from Portuguese flora. J. Pharmacogn. 3, 39-44.

23. Bruneton, J. 2009. Pharmacognosy, Phytochemistry, Medicinal Plants. Lavoisier, Paris, p. 637.

24. Hussain, A. I., Anwar, F., Nigam, P. S., Ashraf, M. and Gilani, A. H. 2010. Seasonal variation in content, chemical composition and antimicrobial and cytotoxic activities of essential oils from four Mentha species. J. Sci. Food. Agric. 90, 1827-1836.
25. Kofidis, G., Bosabalidis, A. and Kokkini, S. 2004. Seasonal variation of essential oils in a linalool-rich chemotype of Mentha spicata grown wild in Greece. J. Essent. Oil. Res. 16, 469-472.

26. Znini, M., Bouklah, M., Majidi, L., Kharchouf, S., Aouniti, A., Bouyanzer, A., Hammouti, B., Costa, J. and Al-Dyab, S. S. 2011. Chemical composition and inhibitory effect of Mentha spicata essential oil on the corrosion of steel in molar hydrochloric acid. Int. J. Electrochem. Sci. 6, 691-704.

27. Dhifi, W., Jelali, N., Mnif, W., Litaiem, M. and Hamdi, N. 2013. Chemical composition of the essential oil of Mentha spicata from Tunisia and its biological activities. J. Food. Biochem. 37, 362-368.

28. Telci, I., Sahbaz, N., Yilmaz, G. and Tugay, M. E. 2004. Agronomical and chemical characterization of spearmint (Mentha spicata L.) originating in Turkey. Econ. Bot. 58, 721-728.

29. Lim, T. T. and Tee, J. J. 2007. Antioxidant properties of several tropical fruits: a comparative study. Food. Chem. 103, 1003-1008.

30. Bellik, Y. and Selles, S.M. A. 2017. In vitro synergistic antioxidant activity of honey-Mentha spicata combination. $J$. Food. Meas. Charact. 11,111-118.

31. Lo Scalzo, R. 2008. Organic acids influence on DPPH scavenging by ascorbic acid. Food. Chem. 107, 40-43.

32. Moldovan, R. I., Oprean, R., Benedec, D., Hanganu, D., Duma, M., Oniga, I. and Vlase, L. 2014. LC-MS analysis, antioxidant and antimicrobial activities for five spieces of Mentha cultivated in Romania. Dig. J. Nanomater. Biostruct. 9, 559-566.

33. Soni, A. and Sosa, S. 2013. Phytochemical analysis and free radical scavenging potential of herbal and medicinal plant extracts. J. Pharmacog. Phytochem. 2, 22-29.

34. Ebrahimzadeh, M. A., Nabavi, S. M. and Nabavi, S. F. 2010. Biological activities of Mentha spicata L. Pharmacology Online 1, 841-848.

35. Nickavar, B., Alinaghi, A. and Kamalinejad, M. 2008. Evaluation of the antioxidant properties of five Mentha species. Iran. J. Pharm. Res. 7, 203-209.

36. Sarer, E., Yağmur-Toprak, S., Otlu, B. and Durmaz, R. 2011. Composition and Antimicrobial activity of the essential oil from Mentha spicata L. subsp. spicata. J. Essent. Oil. Res. 23, 105-108.

37. Nazzaro, F., Fratianni, F., de Martino, L., Coppola, R. and de Feo, V. 2013. Effect of essential oils on pathogenic bacteria. Pharmaceuticals 6, 1451-1474. 